Original Research Paper

\title{
Abundance and Diversity of Diatom Class Bacillariophyceae as Bioindictaor of Pollution in the Waters of Tanjung Luar Fish Landing Based
}

\author{
Niswatul Audah ${ }^{1}$, Lalu Japa ${ }^{1 *}$, M. Yamin ${ }^{1}$ \\ ${ }^{1}$ Program Studi Pendidikan Biologi, Fakultas Keguruan dan Ilmu Pendidikan, Universitas Mataram, Mataram, Indonesia
}

\begin{abstract}
Article History
Received : November $28^{\text {th }}, 2020$

Revised : December $10^{\text {th }}, 2020$

Accepted : December $26^{\text {th }}, 2020$

Published : December 30 ${ }^{\text {th }}, 2020$

*Corresponding Author:

Lalu Japa,

Program Studi Pendidikan

Biologi, Fakultas Keguruan dan

Ilmu Pendidikan, Universitas

Mataram, Mataram, Indonesia

Email: ljapa@gmail.ac.id
\end{abstract}

\begin{abstract}
Tanjung Luar is coastal water used as a waste disposal area for Fish Landing Based (FLB) activities. However, the condition of the waters with phytoplankton as a bioindicator has never been reporting. This research aims to know Bacillariophyceae in terms of abundance, diversity, and measurement of environmental pollution variables. Methods Sampling at the study location was determined by a systematic random sampling method. Data analysis Bacillariophyceae were determined using formula abundance, diversity index, and dominance index. The index of similarity of species between sample points was determined based on the Bray-Curtis Cluster Analysis. Furthermore, the results showed an abundance of Bacillaryophyceae of 322,000 individuals / L classified as low, the diversity index of Bacillariophyceae of 2.162 classified as moderate, and a dominance index of 0.138 (without dominating species). The results showed that the highest species similarity index was between sample points II and III (57.9\%), and the lowest species similarity index between sample points I and II was $23.7 \%$. Water pollution on the waters of PPI Tanjung Luar is classified as moderate pollution level and oligotrophic fertility.
\end{abstract}

Keywords: Abundance; bacillariophyceae; diatom; diversity; tajung luar fish landing.

\section{Pendahuluan}

Tanjung Luar merupakan kawasan pesisir yang sebagian besar masyarakatnya bermata pencaharian sebagai nelayan. Hampir setiap hari aktivitas nelayan, seperti pendaratan dan pemasaran berbagai hasil tangkapan laut dan pelelangan berbagai spesies hiu berlangsung di kawasan tersebut (Fahmi dan Dharmadi 2015; Sentosa dan Dharmadi 2017). Aktivitas-aktivitas yang berlangsung menjadikan kawasan Tanjung Luar ditetapkan sebagai Pangkalan Pendaratan Ikan Tanjung Luar (PPITL) (KKP, 2016).

Penetapannya sebagai PPI memberikan dampak positif dalam mengoptimalkan sumber daya pesisir dan laut. Namun, berdampak negatif, yaitu limbah-limbah yang dihasilkan dapat menjadi sumber pencemaran bagi lingkungan. Hal ini pada akhirnya akan berpengaruh secara langsung maupun tidak langsung terhadap biota air, kesehatan masyarakat sekitarnya, dan tentu saja kesehatan lingkungan PPI sendiri (Siburian et al., 2017; Wahyudi et al., 2017).

Fitoplankton merupakan organisme mikroskopis yang hidup melayang di perairan yang memegang peran penting dalam penentuan produktivitas suatu perairan karena pada tingkat tropik berperan sebagai produsen bagi berlangsungnya proses kehidupan (transfer energi melalui rantai makanan) (Sulistiowati et al., 2016). Keberadaan fitoplankton menjadi indikator biologi dalam mengevaluasi tingkat pencemaran perairan, terutama Bacillariophyceae (diatom) yang umumnya mendominasi perairan laut (Nurbaeti dan Octarina, 2012; Wulandari et al., 2014). Penelitian terkait fitoplankton sebagai bioindikator pencemaran air laut sudah banyak dilakukan dengan berbagai spesies yang ditemukan, yaitu didominasi oleh fitoplankton Bacillariophyceae antara lain: Yuliana et al., (2012), Imran (2016), Faturohman et al., (2016), dan Nasution et al., (2019).

Informasi mengenai tingkat pencemaran air di perairan Pangkalan Pendaratan Ikan Tanjung Luar dengan fitoplankton sebagai bioindikator sampai saat ini belum pernah ada laporannya. Untuk itu, perlu dilakukan penelitian tentang "Kelimpahan dan Keanekaragaman Bacillariophyceae sebagai Bioindikator Pencemaran Air di Perairan Pangkalan Pendaratan Ikan Tanjung Luar". 


\section{Bahan dan Metode}

Jenis penelitian ini adalah deskriptif eksploratif. Pengambilan sampel penelitian dilakukan di perairan PPI Tanjung Luar pada 17 Juni 2020 dari jam 08.00 sampai 09.00. Titik sampel ditentukan berdasarkan teknik systematic random sampling di 5 (lima) titik (Gambar 1). Pengambilan sampel air laut setiap titik diperoleh sebanyak $50 \mathrm{ml}$ dari pemekatan $100 \mathrm{~L}$ air laut menggunakan jaring plankton berukuran mata jaring $20 \mu \mathrm{m}$. Setiap sampel diawet dengan formalin konsentrasi $4 \%$.

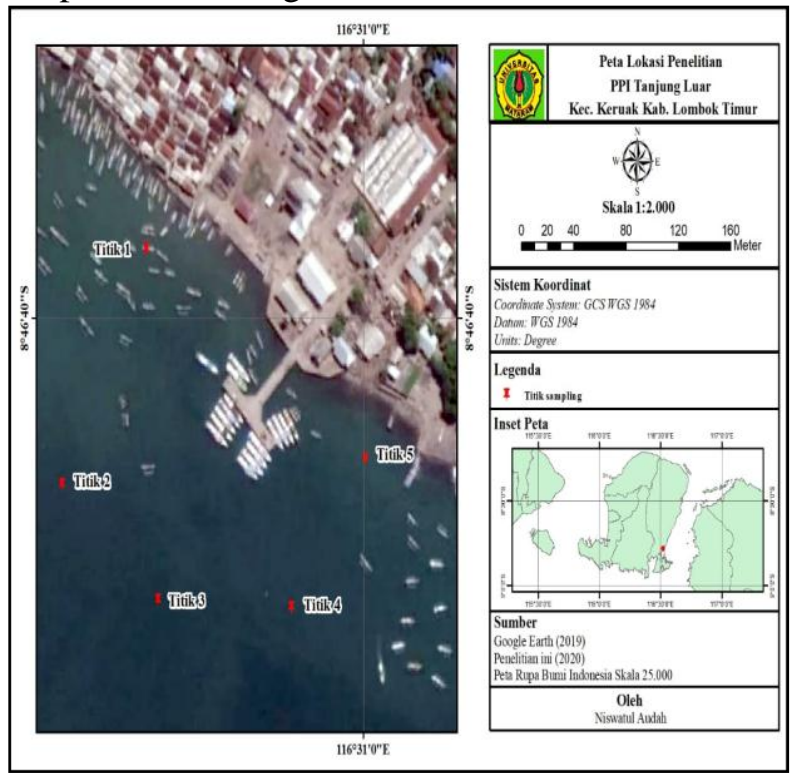

Gambar 1. Peta Lokasi Pengambilan Sampel

Pengamatan dan identifikasi spesies fitoplankton dilakukan di Laboratorium Biologi FKIP Universitas Mataram. Sampel diamati dengan bantuan mikroskop. Pengamatan setiap sampel dilakukan sebanyak 3 kali ulangan. Fitoplankton yang diperoleh diidentifikasi spesiesnya berdasarkan ciri yang tampak (morfologi) dengan mengacu pada buku identifikasi dari Bold dan Whynne (1985), Botes (2003), Wehr dan Sheath (2003), Kandari et al., (2009), Patten et al., (2010), dan Bellinger dan Sigee (2015).

Faktor lingkungan dalam penelitian ini adalah suhu, salinitas, $\mathrm{pH}$, dan oksigen terlarut (DO) diukur langsung pada setiap titik pengambilan sampel di lokasi penelitian.

Data biologi meliputi kelimpahan spesies dari rumus Romimohtarto dan Juwana (2007). Indeks keanekaragaman "Indeks Shannon-Wienner (H') dari rumus Bellinger dan Sigee (2015). Indeks dominansi spesies "Indeks Dominansi Simpson" dari rumus Bellinger dan Sigee (2015) dan indeks kesamaan spesies mengunakan perhitungan BrayCurtis Cluster Analysis dari program Primer versi 7. Data faktor lingkungan dilakukan secara deskriptif.
Analisis tingkat pencemaran berdasarkan kriteria kelimpahan spesies fitoplankton Menurut Raymont (1963) dalam Linus et al., (2016) dan indeks keanekaragaman spesies Wardhana (2006).

\section{Hasil dan Pembahasan}

\section{Kelimpahan Spesies}

Bacillariophyceae yang ditemukan di perairan Pangkalan Pendaratan Ikan (PPI) Tanjung Luar dengan total spesies teridentifikasi sebanyak 27 spesies yang terdiri dari 2 ordo, 12 famili, 15 genus. Jumlah spesies terbanyak ditemukan pada titik sampel IV yaitu 20 spesies. Spesies terendah ditemukan pada titik sampel I sebanyak 7 spesies (Gambar 2). Jumlah total spesies lebih tinggi dibanding 20 spesies (Purnomo et al., 2015) dan 26 spesies (Nurlaelatun et al., 2018). Namun lebih sedikit dibanding 75 spesies (Japa et al., 2013) dan 74 spesies (Aini et al., 2018).

Jumlah individu tertinggi ditemukan pada titik sampel V sebanyak 109 individu, sedangkan jumlah individu terendah ditemukan pada titik IV. Hal ini dipengaruhi oleh kaundungan unsur hara. Rendahnya kandungan unsur hara disebabkan karena daerah yang jauh dari perkampungan warga (daratan) umumnya memiliki konsentrasi sedikit dan sebaliknya Radiarta (2013). Jumlah spesies tertinggi ditemukan pada titik IV sebanyak 20 spesies dan spesies terendah ditemukan pada titik I sebanyak 7 spesies.

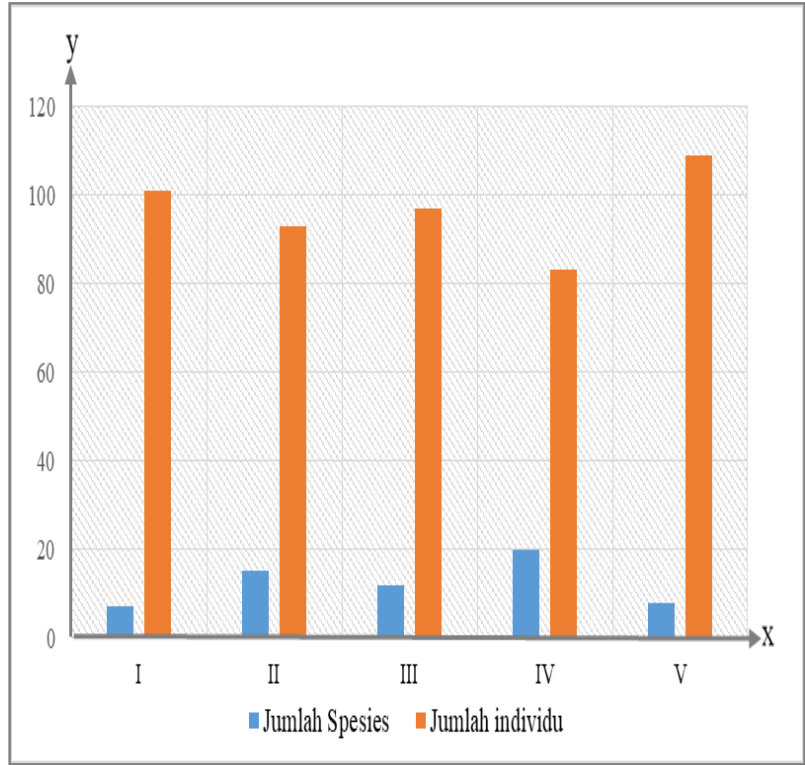

Gambar 2. Proporsi Jumlah Spesies dan Jumlah Individu Bacillariophyceae Setiap Titik Pengambilan Sampel di Perairan PPI Tanjung Luar.

Kelimpahan rata-rata spesies Bacillariophceyae di perairan PPI Tanjung Luar sebesar 322,000 ind/L. Berdasarkan kriteria Raymont 1963 (dalam Lius et al., 2016), jika 
kelimpahan <2000 ind/L maka kelimpahan spesies tersebut tergolong rendah. Kelimpahan spesies ini lebih rendah dibandingkan hasil penelitian Nurlaelatun et al., (2018) yaitu 786,94 ind/L dan Armiani dan Harisanti, (2018) yakni 3.191,333 ind/L.

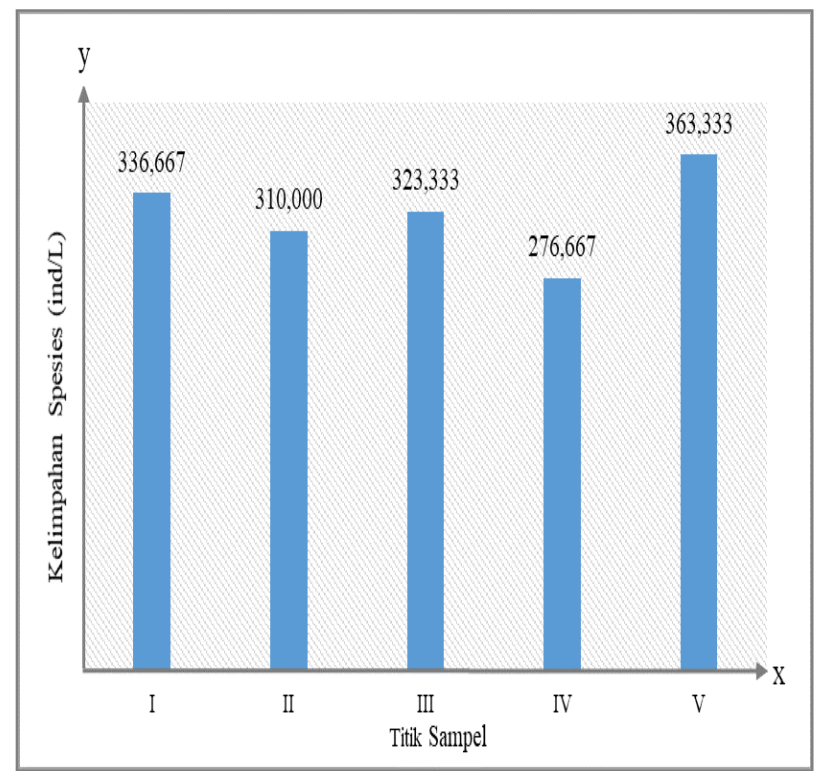

Gambar 3. Perbandingan Nilai Kelimpahan Spesies (N) Bacillariophyceae

Setiap Titik Sampel di Perairan PPI Tanjung Luar.

Spesies Bacillariophyceae yang paling tinggi kelimpahannya adalah Chaetoceros affinis 42,667 ind/L. Kelimpahan Chaetoceros affinis ini lebih rendah dibandingkan dengan kelimpahan yang ditemukan di perairan Selat Bali yakni 7994 ind/L (Khasanah et al., 2013) dan di perairan pantai Jawa Tengah 2542 ind/L (Hidayat, 2018), namun lebih tinggi dari Sulistiowati et al., (2016) di perairan pantai Jayapura pada musim kemarau yakni 0,6 ind/L. Menurut Persada et al., (2019), Chaetoceros affinis adalah salah satu spesies dari genus Chaetoceros kelompok diatom dari bangsa Centrales terbanyak dibandingkan bangsa Penales yang ditemukan di perairan tawar maupun laut. Hal ini diperkuat oleh Hartanto (2020). Tingginya kelimpahan genus ini disebabkan karena mempunyai bentuk dan ukuran yang unik, dengan bentuk seperti rantai atau kumpulan sel dan memiliki chaeta sehingga kurang disukai oleh pemangsa herbivora serta memiliki kemampuan adaptasi lebih baik dibandingkan genus lainnya (Bakhtiar dan Ta'alidin, 2013; Wulandari et al., 2014).

Kelimpahan spesies tertinggi pada titik sampel V yaitu 363,333 ind/L, sedangkan kelimpahan terendah ditemukan pada titik sampel IV sebesar 276,667 ind/L (Gambar 3). Tingginya kelimpahan Bacillariophyceae pada titik sampel V, dapat diduga karena letaknya yang lebih dekat dengan daratan. Hal yang serupa terjadi di perairan selat Alas (Radiarta, 2013) dan di pantai Timur Surabaya yang (Putri dan Sari, 2015). Lokasi yang berada di dekat daratan menyediakan nutrisi lebih besar karena mendapatkan pasokan zat hara dari daratan yang mendukung pertumbuhan Bacillariophyceae.

Rendahnya kelimpahan spesies Bacillariophyceae pada titik sampel IV karena lokasi lebih jauh dari daratan sehingga diduga sedikit mendapat pasokan zat hara untuk pertumbuhan Bacillariophyceae. Hal tersebut juga yang ditemukan Bakhtiar dan Ta'alidin (2013).

\section{Indeks Keanekaragaman}

Indeks rata-rata keanekaragaman spesies Bacillariophyceae di perairan PPI Tanjung Luar yaitu 2,141 yakni berdasarkan Wardhana (2006) tergolong sedang. Indeks keanekaragaman spesies tertinggi terjadi pada titik IV sebesar 2,599 dan terendah terdapat pada titik $\mathrm{V}$ sebesar 1,858 (Gambar 4).

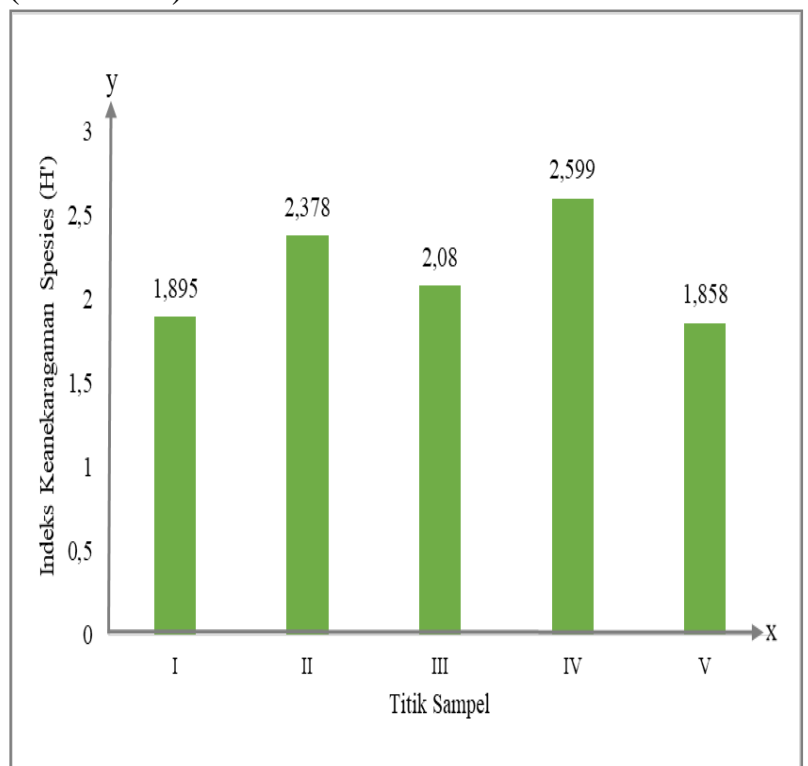

Gambar 4. Perbandingan Indeks Keanekaragaman Spesies (H') Bacillariophyceae Setiap Titik Sampel di Perairan PPI Tanjung Luar.

Hal tersebut menunjukkan bahwa nutrisi tidak banyak mempengaruhi indeks keanekaragaman. Hal serupa dilaporkan oleh Putri dan Sari (2015), bahwa analisis korelasi menunjukkan zat hara memberikan pengaruh yang lemah terhadap indeks diversitas dan diperkuat oleh penelitian Soedibjo (2007), tidak ditemukannya korelasi antara indeks diversitas dan zat hara. 


\section{Indeks Dominansi Spesies}

Indeks dominansi spesies Bacillariophyceae di perairan PPI Tanjung Luar dapat dilihat pada (Gambar 5), bahwa titik sampel V dijumpai tingkat dominansi spesies tertinggi yakni 0,171 , sedangkan terendah ditemukan pada titik sampel IV yakni 0,097. Indeks dominansi rata-rata perairan PPI Tanjung Luar sebesar 0,137 lebih rendah dibanding indeks dominansi spesies Bacillariophycea 0,239 di perairan Pantai Desa Madayin Lombok Timur yang dilaporkan Armiani dan Harisanti (2018). Indeks dominansi tersebut menandakan bahwa tidak ada spesies Bacillariophyceae yang mendominasi perairan PPI Tanjung Luar (Odum, 1993 dalam Purnamaningtyas et al., 2019). Hal serupa yang dilaporkan oleh Wiyarsih et al., (2019).

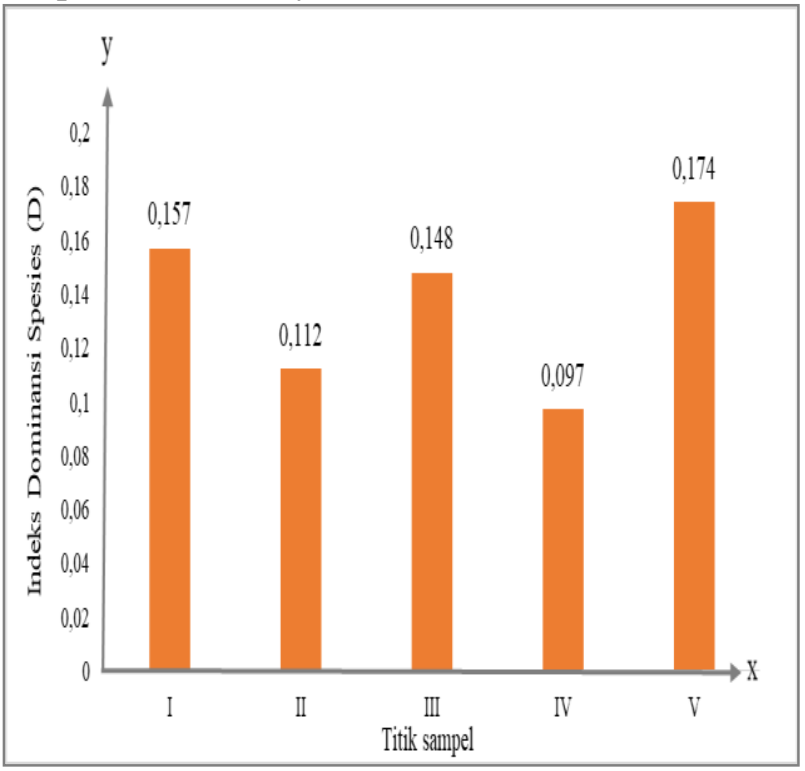

Gambar 5. Perbandingan Indeks Dominansi Spesies (D) Bacillariophyceae Setiap Titik Sampel di Perairan PPI Tanjung Luar.

\section{Indeks Kesamaan Spesies}

Indeks kesamaan spesies Bacillariophyceae antar titik sampel di perairan PPI Tanjung Luar berdasarkan Bray-Curtis Cluster Analysis, diperoleh bahwa antara titik sampel II dan titik sampel III memiliki indeks kesamaan spesies yang tertinggi yaitu $57.9 \%$ dan indeks kesamaan spesies terendah ditemukan antara titik sampel I dan titik sampel II yaitu sebesar 23.7\% (Gambar 6).

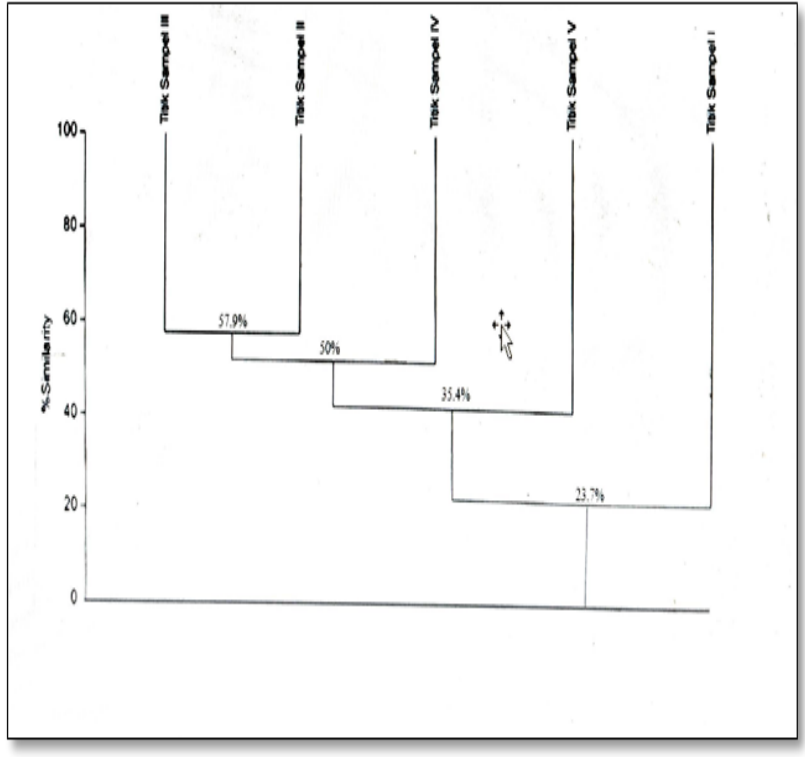

Gambar 6. Perbandingan Indeks Kesamaan Spesies Bacillariophyceae antar Titik Sampel di Perairan PPI Tanjung Luar.

\section{Tingkat Pencemaran Air PPI Tanjung Luar}

Pencemaran air suatu perairan dapat dilihat dari keberadaan parameter biologis. Parameter biologis sangat bergantung pada faktor lingkungan salah satunya ketersediaan suhu, $\mathrm{pH}$, salinitas, dan oksigen terlarut (DO) pada perairan (Tabel 1).

Tabel 1. Hasil Penguuran Faktor Lingkungan PPI Tanjung Luar

\begin{tabular}{clcccccc}
\hline & \multirow{7}{*}{$\begin{array}{c}\text { Faktor } \\
\text { No }\end{array}$} & \multicolumn{5}{c}{ TITIK } & Rata- \\
\cline { 3 - 6 } & lingkungan & I & II & III & IV & V & Rata \\
\hline 1 & $\begin{array}{l}\text { Suhu }\left({ }^{0} \mathrm{C}\right) \\
\text { Salinitas }\end{array}$ & 29,7 & 29,2 & 29,2 & 28,7 & 28 & 28,96 \\
2 & $(\% / 00)$ & 30 & 33 & 33 & 33 & 34 & 32,6 \\
3 & $\mathrm{Ph}$ & 7 & 7 & 7 & 7 & 7 & 7 \\
4 & DO $(\mathrm{mg} / \mathrm{l})$ & 6 & 6,2 & 7 & 6,8 & 6,8 & 6,56 \\
\hline
\end{tabular}

Keberadaan suhu di perairan berpengaruh terhadap proses pertumbuhan fitoplankton sebagai produsen primer. Suhu dapat mempengaruhi laju fotosintesis secara langsung maupun tidak langsung (Hamuna et al., 2018). Kisaran suhu kelima titik sampel yaitu $28-29,7^{\circ} \mathrm{C}$, suhu rata-rata perairan yaitu $28,96^{\circ} \mathrm{C}$. Kisaran suhu yang lebih tinggi dibandingkan suhu di perairan Pesisir Lombok Timur pada Juli 2019 yang dilaporkan oleh Patech et al., (2020) yaitu berkisar $24,4-24,8^{\circ} \mathrm{C}$. Suhu ini masih masih dalam batas yang normal untuk kehidupan biota laut, yaitu $28-30^{\circ} \mathrm{C}$ memenuhi syarat untuk pertumbuhan dan perkembngan fitoplankton (KMNLH, 2004). Hal ini diperkuat 
oleh Effendi (2003), bahwa suhu optimum $20^{\circ}$ $30^{\circ} \mathrm{C}$ optimum untuk pertumbuhan fitoplankton salah satunya dari algae filum diatom.

Salinitas yang terdapat di perairan PPI Tanjung Luar yaitu berkisar antara $30-34 \%$ dengan rata-rata salinitas sebesar $32,6 \%$. Kisaran yang lebih tinggi dibandingkan di perairan Pesisir Lombok Timur pada Juli 2019 yaitu 27,3 -31,9\% yang dilaporkan oleh Patech et al., (2020). Salinitas yang terdapat di perairan PPI Tanjung Luar masih dalam batas yang normal untuk kehidupan biota laut kecuali titik 5 yang kurang mendukung untuk kehidupan biota laut secara optimum (KMNLH, 2004).

Derajat keasaman atau $\mathrm{pH}$ perairan PPI Tanjung Luar adalah 7. Kisaran $\mathrm{pH}$ yang lebih rendah dibandingkan perairan Pesisir Lombok Timur pada Juli 2019 yang dilaporkan oleh Patech et al., (2020) yaitu berkisar 7,10 - 7,11. pH tersebut mendukung keberadaan diatom, hal ini sejalan dengan Barsanti dan Gualtieri (2014) bahwa pH 7 9 sangat mendukung pertumbuhan fisiologis sel Bacillariophyceae. Nilai $\mathrm{pH}$ ini masih dalam kategori normal untuk biota laut dan untuk perairan pelabuhan 6,5 - 8,5 (KMNLH, 2004).

Oksigen terlarut dalam air sangat penting untuk kelangsungan hidup organisme laut termasuk fitoplankton. Kandungan DO di sekitar perairan PPI Tanjung Luar pada 5 titik sampel berkisar antara 6.0 - $7.0 \mathrm{mg} / \mathrm{L}$ dengan rata-rata $6,56 \mathrm{mg} / \mathrm{L}$ yang menunjukkan DO $>5 \mathrm{mg} / \mathrm{L}$. Kisaran DO yang lebih tinggi dibandingkan di perairan Pantai Labuhan Haji Lombok Timur yang dilaporkan Haerudin dan Putra (2019) yaitu 6,0 mg/L. Nilai DO yang masih sesuai dengan baku mutu air laut yang sesuai untuk biota laut (KMNLH, 2004).

Indeks keanekaragaman spesies Bacillariophyceae rata-rata di perairan PPI Tanjung Luar sebesar 2,162 dapat menggambarkan tingkat tercemar perairan tergolong sedang. Indeks keanekaragaman spesies ini menunjukkan bahwa perairan PPI Tanjung Luar memiliki stabilitas komunitas sedang dan terindikasi adanya pencemaran dengan tingkat tercemar sedang (Agustina dan Poke, 2016).

Kelimpahan rata-rata spesies Bacillariophyceae di perairan PPI Tanjung Luar sebesar 322,000 ind/L dapat menggambarkan tingkat kesuburan perairan oligotropik oleh Raymont, 1963 (dalam Linus et al., 2016). Oligotropik adalah perairan dengan kesuburan rendah. Oligotropik merupakan cemaran perairan tingkat ringan berasal dari sedikit senyawa organik dan anorganik (Wardhana, 2006). Alga dikatakan blooming apabila mencapai $10^{6}$ ind/L (Gurning et al., 2020). Chaetoceros merupakan spesies dengan kelimpahan tertinggi, spesies ini tidak menghasilkan racun (toxin) namun ketika terjadi blooming, alga jenis ini memiliki efek berbahaya yaitu dapat menyebabkan iritasi yang merangsang pembentukan lendir pada insang ikan sehingga dapat membuat ikan menjadi susah untuk bernafas dan akhirnya mati (Choirun et al., 2015).

\section{Kesimpulan}

Berdasarkan hasil penelitian dapat disimpulkan bahwa: Kelimpahan spesies Bacillariophyceae di perairan PPI Tanjung Luar tergolong rendah (322,000 ind/L). Indeks keanekaragaman spesies Bacillariophyceae di perairan PPI Tanjung Luar sebesar 2,162 yaitu tergolong sedang. Indeks dominansi spesies di perairan PPI Tanjung Luar sebesar 0,138 yaitu tergolong rendah (tidak ada yang mendominasi). Indeks kesamaan spesies tertinggi ditemukan antara titik sampel II-III sebesar 57.9\% dan terendah pada antara titik sampel I-II sebesar 23.7\%. Tingkat pencemaran air di perairan PPI Tanjung Luar tercemar sedang dan kesuburan oligotropik.

\section{Ucapan terima kasih}

Penelitian ini dapat dilaksanakan dengan baik berkat bantuan dari berbagai pihak, oleh sebab itu peneliti mengucapkan terima kasih kepada Dosen Pembimbing, Pegawai laboratorium dan temanteman yang telah membantu.

\section{Referensi}

Agustina, S. S., \& Poke, A. A. M. (2016). Keanekaragaman Fitoplankton sebagai Indikator Tingkat Pencemaran Perairan Teluk Lalong Kota Luwuk. Jurnal Balik Diwa, 7(2): 1-6

Aini, Y. Q., A. A. Idrus., \& L. Japa. (2018). Komunitas Plankton pada Perairan Habitat Mangrove di Gili Sulat Lombok Timur. Prosiding Seminar Nasional Pendidikan Biologi, 32-40.

Armiani, S., \& Harisanti, B. M. (2018). Kualitas Air Laut ditinjau Indeks Keanekaragaman Fitoplankton di Perairan Pantai Desa Madayin Lombok Timur. Jurnal Ilmiah Biologi, 6(2): 1-6.

Bakhtiar, D., \& Ta'alidin, Z. (2013). Kelimpahan 
dan Kandungan Klorofil-A Fitoplankton di Perairan Pulau Enggano. Jurnal Mitra Bahari, 7(1): 28-39.

Barsanti, L., \& Gualtieri, P. (2006). AlGAE: Anatomy, Biochemistry, and Biotechnology. United States of America: CRC Press.

Bellinger, E. G., and Sige, D. C. (2015). Freshwater Algae Identification, Enumeration, and Use as Bioindicators. India: Willey Backwell.

Bold, H. C., and Whynne, M. J. (1985). Introduction to the Algae Structure and Reproduction. United States of America: Pretice-Hall Inc.

Botes, L. (2003). Phytoplankton Identification Catalogue - Saldanha Bay, South Africa. London: GloBallast Monograph.

Choirun, A., Sari, S. H. J., \& Iranawati, F. (2015). Identifikasi Fitoplankton Spesies Harmfull Algae Bloom (Hab) Saat Kondisi Pasang di Perairan Pesisir Brondong, Lamongan, Jawa Timur. Jurnal Ilmu Kelautan Dan Perikanan, 25(2): 58-66.

Effendi, H. (2003). Telaah Kualitas Air Bagi Pengelolaan Sumber Daya dan Lingkungan Perairan. Yogyakarta: Kanisius.

Fahmi \& Dharmadi (2015). Pelagic Shark Fisheries of Indonesia's Eastern Indian Ocean Fisheries Management Region. African Journal of Marine Science, 37(2): 259-265.

Faturohman, I., Sunarto, \& Nurruhwati, I. (2016). Korelasi Kelimpahan Plankton dengan Suhu Perairan Laut Di Sekitar PLTU Cirebon. Jurnal Perikanan Kelautan, 7(1): 115-122.

Haerudin, \& Putra, A. M. (2019). Analisis Baku Mutu Air Laut Untuk Pengembangan Wisata Bahari di Perairan Pantai Labuhan Haji Kabupaten Lombok Timur. Jurnal Geodika, 3(1): 13-18.

Hamuna, B., Tanjung, R. H. R., Suwito, Maury, H. K., \& Alianto. (2018). Kajian Kualitas Air Laut dan Indeks Pencemaran Berdasarkan Parameter Fisika-Kimia di Perairan Distrik Depapre, Jayapura. Jurnal Ilmu Lingkungan, 16(1): 35-43.

Hartanto, A. T. (2020). Plankton Indexes and Heavy
Metal Pollution in Kendal Coastal Waters, Indonesia. Aquculture, Aquarium, Conservation dan Legislation, 13(1): 46-63.

Hidayat, J. W. (2018). The Water Quality and Cultivant Enrichment Potency of Pond Based on Saprobic Index at North Coastal Waters of Central Java , Indonesia. Journal of Physics, 1025(1): 1-8.

Japa, L., Suripto, \& Mertha, I. G. (2013). Hubungan Kuantitatif Fitoplankton dan Zooplankton Perairan Suaka Perikanan Gili Ranggo Teluk Serewe Lombok Timur. Jurnal Biologi Tropis, 13(1): 45-54.

Kandari, M. A., Yamani, F. A., and Rifaie, K. A. (2009). Marine Phytoplankton Atlas of Kuwait's Waters. Kuwait: Kuwait Institute for Scientific Research.

Kementerian Kelautan dan Perikanan Republik Indonesia. (2016). Keputusan Menteri Kelautan dan Perikanan Republik Indonesia Nomor 33/KEPMEN-KP/2016 tentang Penetapan Pelabuhan Perikanan Tanjung Luar Sebagai Pangkalan Pendaratan Ikan Tanjung Luar, di Provinsi Nusa Tenggara Barat. Jakarta: KKP.

Kementerian Negara Lingkungan Hidup. (2004). Keputusan Menteri Negara Lingkungan Hidup Nomor 51 Tahun 2004, Tentang Baku Mutu Air Laut. Jakarta: Kementrian Negara Lingkungan Hidup.

Khasanah, R. I., Sartimbul, A., \& Herawati, E. Y. (2013). Kelimpahan dan Keanekaragaman Plankton di Perairan Selat Bali. Ilmu Kelautan, 18(4): 193-202.

Linus, Y., Salwiyah, \& Irawati, N. (2016). Status Kesuburan Perairan Berdasarkan Kandungan Klorofil- a di Perairan Bungkutoko Kota Kendari. Jurnal Manajemen Sumber Daya Perairan, 2(1): 101-111.

Nasution, A., Widyorini, N., \& Purwanti, F. (2019). Analisis Hubungan Kelimpahan Fitoplankton dengan Kandungan Nitrat dan Fosfat di Perairan Morosari, Demak. Journal of Maquares, 8(2): 78-86.

Nurbaeti, N., \& Octorina, P. (2012). Hubungan Keanekaragaman Fitoplankton dengan 
Kualitas Air di Situ Minera Bekas Galian Pasir Gekbong, Cianjur-Jawa Barat. Jurnal Pertanian-UMMI, 1(2): 1-10.

Nurlaelatun, H., Japa, L., \& Santoso, D. (2018). Keanekaragaman dan Kelimpahan Diatom (Bacillariophyceae) di Pantai Jeranjang Desa Taman Ayu Kecamatan Gerung Kabupaten Lombok Barat. Jurnal Biologi Tropis, 18(1): 13-20.

Patech, L. R., Syukur, A., \& Santoso, D. (2020). Kelimpahan dan Keanekragaman Spesies Echinodermata sebagai Indikator Fungsi Ekologi Lamun di Perairan Pesisir Lombok Timur. Jurnal Sains Teknologi dan Lingkungan, 6(1): 40-49.

Patten, V. P., J. Y. Li., and Wikfors, G. H. (2010). A Student's Guide to Common Phytoplankton of Long Island Sound. Florida: Connecticut Sea Grant College Program 2012.

Persada, A. Y., Navia, Z. I., Saputri, A., Putri, K. A., \& Al Fajar, B. (2019). Inventaris Jenis Fitoplankton di Pulau Pusong, Langsa, Aceh. Journal of Islamic Science and Technology, 5(1): 67-75.

Purnamaningtyas, S. E., Mujiyanto, \& Riswanto. (2019). Distribusi dan Kelimpahan Fitoplankton di Teluk Gerupuk, Nusa Tenggara Barat. Akuatika Indonesia, 4(1): 24-30.

Purnomo, A. A., Junitha, I. K., \& Suartini, N. M. (2015). Variasi Spesies Diatom Pada Tipe Perairan Berbeda Untuk Kepentingan Forensik Sebagai Petunjuk Kematian Akibat Tenggelam. Simbiosis: Journal of Biological Sciences, 3(1): 247-257.

Putri, S. I. P., \& Sari, S. H. J. (2015). Struktur Komunitas Fitoplankton dan Kaitannya dengan Ketersediaan Zat Hara dan Parameter Kualitas Air Lainnya di Perairan Timur Surabaya. Depik, 4(2): 79-86.

Radiarta, I. N. (2013). Hubungan Antara Distribusi Fitoplankton dengan Kualitas Perairan Di Selat Alas, Kabupaten Sumbawa, Nusa Tenggara Barat. Bumi Lestari, 13(2): 234243.
Romimohtarto, K., \& Juwana, S. (2007). Biologi Laut: Ilmu Pengetahuan tentang Biota Laut. Jakarta: Djambatan.

Sentosa, A. A., \& Dharmadi. (2017). Hasil Tangkapan dan Kelimpahan Relatif Beberapa Jenis Hiu yang Didaratkan di Tanjung Luar, Lombok Catch and Relative Abundance of Some Sharks Landing in Tanjung. Widyariset, 3(2): 131-142.

Siburian, R., Simatupang, L., \& Bukit, M. (2017). Analisis Kualitas Perairan Laut Terhadap Aktivitas di Lingkungan Pelabuhan Waingapu-Alor Sumba Timur. Jurnal Pengabdian Kepada Masyarakat, 23(1): 225-232.

Soedibjo, B. S. (2007). Pengaruh Faktor Lingkungan Terhadap Distribusi Spasial Komunitas Zooplankton di Teluk Klabat, Perairan Bangka Belitung. Oseanologi dan Limnologi di Indonesia, 33: 27-63.

Sulistiowati, D., Tanjung, R. H. R., \& Lantang, D. (2016). Keragaman dan Kelimpahan Plankton sebagai Bioindikator Kualitas Lingkungan di Perairan Pantai Jayapura. Jurnal Biologi Papua, 8(2): 79-96.

Wahyudi, A., Lubis, E., \& Pane, A. B. (2017). Strategi Pencegahan Pencemaran Lingkungan Pelabuhan Perikanan: Kasus Pelabuhan Perikanan Nusantara Palabuhanratu. ALBACORE, 1(2): 139-152.

Wardhana. (2006). Pelatihan Penyusun Analisis Mengenai Dampak Lingkungan: MetodaPrakiraan Dampak dan Pengelolaannya pada Komponen Biota Akuatik. Jakarta: Universitas Indonesia.

Wehr J.D., and Sheath, R. G. (2003). Freshwater Algae of North America Ecology and Classification. Sydney Tokyo: Academic Press.

Wiyarsih, B., Endrawati, H., \& Sedjati, S. (2019). Komposisi Dan Kelimpahan Fitoplankton Di Laguna Segara Anakan, Cilacap. Buletin Oseanografi Marina, 8(1): 1-8.

Wulandari, D. Y., Tunjung, N., Pratiwi, M., \& Adiwilaga, E. M. (2014). Distribusi Spasial Fitoplankton di Perairan Pesisir Tangerang. Jurnal Ilmu Pertanian Indonesia, 19(3): 156 